Several months later, she arrived in casualty again having cut her vagina with scissors on the previous day, sustaining multiple superficial lacerations of the vagina and cervix. She was admitted for observation and after 4 days discharged herself again refusing offers of further help.

\section{Comment}

Her self-mutilating behaviour shares several features with the typical wrist cutters. She plans each incident carefully enjoying the anticipation of the event. She feels no pain when cutting and feels relief and fascination watching her blood flow. Even her major vaginal lacerations were painless for a period of some $24 \mathrm{hr}$.

The case described by Goldfield and Glick (1970) was a girl of 19 who scratched and gorged her internal genitalia with her finger-nails, leading to prolonged investigation of vaginal bleeding for which she received three dilatation and curettages, a cervical conization and multiple cauterizations, and was pleading for a hysterectomy. Gerstle, Guttmacher and Brown's (1957) case was regarded as one of malingered placenta praevia. The patient mutilated her vagina with a hatpin or knitting needle in late pregnancy on four occasions, producing enough bleeding to justify a caesarean section on the grounds of presumed placenta praevia. French and Nelson's (1972) case lacerated her vulva superficially with a razor blade on one occasion.

The first case sought multiple gynaecological procedures and wanted a hysterectomy, her disturbance starting after the birth of an illegitimate child. The second case gained delivery by caesarean section of a pregnancy she found unbearable and our patient started her mutilations when fearing pregnancy, and succeeded in gaining a reassuring dilatation and curettage.

It is an open question whether similar episodes of self-mutilation when less exaggerated and bizarre, may not be more common than is usually supposed, and may pass unnoticed and indeed succeed in inducing the various gynaecological procedures the patients may be seeking.

\section{References}

French, A.P. \& Nelson, H.L. (1972) Genital self-mutilation in women. Archives of General Psychiatry, 27, 618.

Gersble, M.L., Guttmacher, A.F. \& Brown, F. (1957) A case of recurrent malingered placenta praevia. Journal of Mount Sinai Hospital, 24, 641.

GoldFIELD, M.D. \& GLICK, I.R. (1970) Self-mutilation of the female genitalia: a case report. Diseases of the Nervous System, 31, 843.

\title{
The syndrome of dilutional hyponatremia
}

\author{
D. P. MisRa \\ B.Sc., M.B., M.R.C.P. \\ Department of Geriatric Medicine, Bristol General Hospital
}

\begin{abstract}
Summary
Three cases of dilutional hyponatremia are presented. All had ADH bio-assay at the height of biochemical abnormality and the values were found to be normal. The first two cases were due to cortisol deficiency. An interesting feature of these two cases was a high exchangeable sodium which was corrected by administration of cortisone, suggesting that cortisol plays some part in the distribution of sodium between the extracellular and the intracellular space. The third case occurred in association with urinary tract infection. Similar findings have been reported in elderly patients with pneumonia and have been presumed to be due to inappropriate secretion of ADH on indirect evidence. ADH assay has rarely been done and has never been found to be high. On the basis of the findings observed in the three cases, it is suggested that factors other than ADH excess and cortisol deficiency are involved in the production of dilutional hyponatremia.
\end{abstract}

\section{Introduction}

Hyponatremia associated with fluid retention and expansion of body fluid presents a complex problem. The diagnosis is based on low plasma sodium, low plasma osmolarity, a high extracellular fluid (ECF) volume or plasma volume, a low or low normal plasma urea and absence of clinical oedema. This syndrome has been described in various disorders, namely, carcinoma of bronchus, pneumonia, tuberculosis of lungs, encephalitis, meningitis and postoperative states. The underlying cause in these cases has usually been attributed to abnormal antidiuretic hormone (ADH) production.

Schwartz et al. (1957) described this syndrome in two cases of bronchogenic carcinoma and proposed that inappropriate secretion of ADH was responsible. Lee, Jones and Barraclough (1964) lent support to the above hypothesis. They assayed ADH levels in urine, blood and tumour tissue and found the level 
of $\mathrm{ADH}$ to be higher in the tumour tissue than blood. They suggested that the tumour elaborated the hormone.

A report on three cases forms the basis of this paper. The first two were due to cortisol deficiency. The object of study in these two cases was threefold: (1) to find out if ADH was produced in excess; (2) to estimate the exchangeable sodium in view of a low plasma sodium, and (3) to observe the effect of cortisone administration. The third case occurred in a patient with urinary tract infection. There was no evidence of pituitary or adrenal dysfunction and the patient had spontaneous remission. An estimation of urinary ADH was done at the height of biochemical abnormality to assess whether the hormone was responsible for the disorder.

\section{Case 1}

A woman of 68 was admitted to hospital with a 6-month history of generalized weakness, lethargy, loss of appetite and weight. She was confused at times.

On examination, she was pale and thin. The pulse was regular and the blood pressure $170 / 90 \mathrm{mmHg}$. The distribution of hair was abnormal. The pubic and axillary hair was absent. The remainder of general examination was normal. Investigations: plasma urea 11-19 $\mathrm{mg} \%$; plasma sodium 114-118 $\mathrm{mEq} / 1$; plasma potassium $2.9-3.5 \mathrm{mEq} / 1$; plasma bicarbonate $79-84 \mathrm{mEq} / 1$; plasma osmolarity 240 $\mathrm{mmol} / \mathrm{kg}$; plasma volume $53.5 \mathrm{ml} / \mathrm{kg}$; exchangeable sodium $49.6 \mathrm{mEq} / \mathrm{kg}$; exchangeable potassium 31 $\mathrm{mEq} / \mathrm{kg}$; bromine space $355 \mathrm{ml} / \mathrm{kg}$; haemoglobin $11.5 \mathrm{~g} \%$; chest and skull X-rays, within normal limits) plasma cortisol $1 \mu \mathrm{g} / 100 \mathrm{ml} ; 30 \mathrm{~min}$ after injection of Synacthen the plasma cortisol was 15 $\mu \mathrm{g} / 100 \mathrm{ml}$.

These findings suggested that the patient had dilutional hyponatremia associated with cortisol deficiency due to hypopituitarism. Urinary ADH was 5.9 i.u. in $24 \mathrm{hr}$ and urinary aldosterone 2.3-5.9 $\mu \mathrm{g} / \mathrm{l}$.

The patient was treated with oral cortisone $25 \mathrm{mg}$ daily. Eight weeks later she was clinically much better. Further investigations showed a corresponding return to normal (plasma sodium $138 \mathrm{mEq} / 1$; plasma potassium $3.8 \mathrm{mEq} / 1$; plasma chloride 97 $\mathrm{mEq} / 1$; plasma bicarbonate $31 \mathrm{mEq} / 1$; plasma urea $20 \mathrm{mg} \%$; plasma osmolarity $287 \mathrm{mmol} / \mathrm{kg}$ and exchangeable sodium $39.8 \mathrm{mEq} / \mathrm{kg}$ ); exchangeable potassium $30.4 \mathrm{mEq} / \mathrm{kg}$; bromine space 259 $\mathrm{ml} / \mathrm{kg}$.

\section{Case 2}

A man of 68 years was admitted to hospital with several months history of lethargy, anorexia and
3 stone weight loss. He had had a partial gastrectomy for duodenal ulcer in 1949.

On examination, he was pale and wasted. There was no pigmentation. There was absence of pubic and axillary hair. Blood pressure was $100 / 50 \mathrm{mmHg}$. He had a marked dorsal kyphosis. The remainder of the examination was normal. Investigations: plasma urea $15-17 \mathrm{mg} \%$; plasma sodium $120-125 \mathrm{mEq} / 1$; plasma potassium $3.6-3.9 \mathrm{mEq} / 1$; plasma chloride 90-92 $\mathrm{mEq} / 1$; plasma bicarbonate $24-26 \mathrm{mEq} / 1$; plasma osmolarity $261 \mathrm{mmol} / \mathrm{kg}$; exchangeable sodium $57.5 \mathrm{mEq} / \mathrm{kg}$; exchangeable potassium 35.4 $\mathrm{mEq} / \mathrm{kg}$; bromine space $341 \mathrm{ml} / \mathrm{kg}$; plasma cortisol at 9.00 a.m. and 12 midnight was $3 \mu \mathrm{g} / 100 \mathrm{ml}$; a prolonged ACTH stimulation test supported the diagnosis of hypopituitarism. Serum calcium 8.5 $\mathrm{mg} \%$; phosphorus $2.8 \mathrm{mg} \%$; alkaline phosphatase 19 KA units. Chest X-ray showed bilateral fibrotic lesions on the upper zones. Sputum for tubercle bacillus was consistently negative. Urinary $\mathrm{ADH} 6$ i.u. $/ 24 \mathrm{hr}$ and urinary aldosterone $3.4 \mu \mathrm{g} / 1$.

These results suggested dilutional hyponatremia with hypopituitarism. There was also osteomalacia secondary to partial gastrectomy. The pulmonary lesion was considered to be due to tuberculosis of doubtful activity. Treatment was started with streptomycin $500 \mathrm{mg}$ daily, isoniazid $300 \mathrm{mg}$ daily, rifampicin $450 \mathrm{mg}$ daily, oral cortisone $25 \mathrm{mg}$ daily and calciferol $1.25 \mathrm{mg}$ daily.

Three weeks later he was clinically much improved but the biochemical results were unaltered (plasma urea $28 \mathrm{mg} \%$; plasma sodium $122 \mathrm{mEq} / \mathrm{l}$; plasma potassium $3.6 \mathrm{mEq} / 1$; plasma chloride 86 $\mathrm{mEq} / 1$; plasma bicarbonate $30 \mathrm{mEq} 1$; plasma osmolarity $262 \mathrm{mmol} / \mathrm{kg}$; exchangeable sodium $52.2 \mathrm{mEq} / \mathrm{kg}$ ). After a further 3 weeks they were found to be normal (plasma urea $34 \mathrm{mg} / \%$; plasma sodium $139 \mathrm{mEq} / 1$; plasma potassium $3.5 \mathrm{mEq} / 1$; plasma chloride $95 \mathrm{mEq} / 1$; plasma bicarbonate 34 $\mathrm{mEq} / 1$; plasma osmolarity $282 \mathrm{mmol} / \mathrm{kg}$; exchangeable sodium $40.5 \mathrm{mEq} / \mathrm{kg}$; exchangeable potassium $35 \mathrm{mEq} / \mathrm{kg}$; bromine space $273 \mathrm{ml} / \mathrm{kg}$ ).

\section{Case 3}

A woman of 85 was admitted with a history of haematuria of 1 week's duration. She was exhausted and felt dizzy when she tried to get up.

On examination, she was pale and thin. The pulse was regular and the blood pressure $180 / 100 \mathrm{mmHg}$. The kidneys were not palpable. No other clinical abnormality was detected.

Investigations: intravenous pyelogram was normal; cystoscopy showed inflammation of the trigone; mid-stream urine showed pus cells and a heavy growth of Bacillus coli. Biochemical: plasma urea 14-19 $\mathrm{mg} \%$; plasma sodium $119-123 \mathrm{mEq} / 1$; plasma potassium $3.3-3.5 \mathrm{mEq} / 1$; plasma chloride 
$75 \mathrm{mEq} / 1$; plasma bicarbonate $37-39 \mathrm{mEq} / 1$; plasma osmolarity $235 \mathrm{mmol} / \mathrm{kg}$; plasma volume $54 \mathrm{ml} / \mathrm{kg}$; urinary ADH 2 i.u. $/ 24 \mathrm{hr}$ and aldosterone $2.4 \mu \mathrm{g} / 1$; plasma cortisol $28 \mu \mathrm{g} / 100 \mathrm{ml}$.

The laboratory tests showed evidence of dilutional hyponatremia and urinary tract infection. There was nothing to suggest pituitary or adrenal disease. She was treated with oral ampicillin for 2 weeks. Fluid was retricted to $800 \mathrm{ml}$ daily. After 6 weeks, she showed a complete remission (plasma sodium $136 \mathrm{mEq} / 1$; plasma potassium $4.5 \mathrm{mEq} / 1$; plasma chloride $91 \mathrm{mEq} / 1$; plasma bicarbonate $27 \mathrm{mEq} / 1$; plasma urea $19 \mathrm{mg} \%$; plasma osmolarity 290 $\mathrm{mmol} / \mathrm{kg}$.)

\section{Discussion}

The pathophysiology of dilutional hyponatremia has aroused considerable interest. Abdul et al. (1967) stated that the glucocorticoids promote normal water diuresis by inhibiting the secretion of ADH from the neurohypophysis and further suggest that hypersecretion of ADH may play an important role in the abnormal water metabolism which occurs as a result of adreno-cortical insufficiency.

On the other hand, Kleeman et al. (1960) believe that glucocorticoids have a direct effect on the renal tubules independent of ADH. Green, Harrington and Valsun (1970) lent support to the view. As a result of experimental study on rats, they showed that ADH was not essential for inhibition of acute water diuresis in adrenal insufficiency.

The first two cases reported in the paper showed no excess of ADH secretion and had cortisol deficiency, thus supporting the view of Kleeman et al. (1960). A notable feature of these two cases was a high exchangeable sodium. This meant that the total body sodium was higher than normal despite a low serum level. It was interesting to note that after cortisone administration the level returned to normal. This suggests that cortisol is concerned with the distribution of water and electrolytes between the extracellular and intracellular compartments. It was surprising that with such a large bromine space and a high exchangeable sodium there was no clinical oedema.

The clinical and biochemical findings in Case 3 were typical of inappropriate secretion of $\mathrm{ADH}$; as was the case described by Rosenow, Segar and Zehr (1972); the former was associated with urinary tract infection, the latter with pneumonia. Bioassay of ADH was not performed in Rosenow's case; it was found to be normal in my patient. A high level of $\mathrm{ADH}$ is presumed to be responsible for hyponatremia, the mechanism of production is obscure. Johnson and Moore (1969) by experimental study in dog showed that there was an inverse relationship between the left atrial pressure and plasma ADH level in the absence of alterations in plasma osmolarity or renal haemodynamics. On the basis of these findings it was suggested that inadequate filling of the left atrium due to decreased blood flow through the pulmonary vascular bed could be the cause of the elevated blood vasopressin in cases of pneumonia. Alternatively, it is possible that $\mathrm{ADH}$ like substance is elaborated by infected lung tissue. Helmuth et al. (1970) showed increased ADH activity in the urine and lung tissue of a patient suffering from pulmonary tuberculosis.

However, there are some patients who show a normal ADH activity. It is likely that some other mechanism operates in these cases. The action of ADH on renal tubules is not fully understood but it is believed that the pores in the distal tubucle are opened up, which might account for the reabsorption of osmotically free water. This idea is based on the experimental work of Koeford-Johnsen and Ussing (1953) who showed that ADH increased the osmotic flow through the frog's skin and suggested that this action was achieved by increasing the pore size.

Most patients described have been elderly people, who show overall reduction in renal function and in such cases a bacterial or viral toxin may modify the function of renal tubules. It is possible that under these circumstances the action of ADH on tubules is exaggerated, which might account for dilution as well as hyponatremia.

No matter how the condition is produced, whether by excessive production of $\mathrm{ADH}$ or by a temporary breakdown in renal mechanism, the outlook seems favourable. There are only one or two isolated reports on the subject, but the observations so far indicate that once the infection is over there is a spontaneous remission, occasionally assisted by fluid restriction.

\section{Acknowledgments}

I wish to thank Dr W. H. Lloyd and Dr A. C. M. Windsor for their advice and suggestions. I am extremely grateful to Professor W. Lee for the estimation of ADH and his comment on the cases, and to Searle Scientific Laboratory for the estimation of aldosterone.

\section{References}

Abdul, J.A., George, B.C., Gonzalez-Auvesh, C. \& DingMAN, J.F. (1967) Increased plasma arginine vasopression in clinical adrenocortical insufficiency and its inhibition by glucocorticoids. Journal of Clinical Investigation, 46, 111.

Green, H.H., Harrington, A.R. \& Valsun, H. (1970) On the role of anti-diuretic hormone in the inhibition of acute water diuresis in adrenal insufficiency and the effects of gluco and meusato corticoids in reversing the inhibition. Journal of Clinical Investigation, 49, 1724.

Helmuth, V., Massry, S.G., Fallet, R., Kaplan, L. \& Kleeman, C.R. (1970) Anti-diuretic principle in tuberculous lung tissue of a patient with pulmonary tuberculosis and hyponatremia. Annals of Internal Medicine, 72, 383. 
Johnson, J.A. \& Moore, W.W. (1969) Small changes in left atrial pressure and plasma anti-diuretic hormone titres in dogs. American Journal of Physiology, 217, 210.

Kleeman, C.R.J., Koplowitz, M.H., Cutler, M.R. \& Dowling, J.T. (1960) Mechanism of impaired water excretion in adrenal and pituitary insufficiency. II. Interrelationships of adrenal corticosteroids and anti-diuretic hormone in normal subjects and in diabetes insipidus. Journal of Clinical Investigation, 39, 1472.

Koeford-Johnsen, V. \& Ussing, H.H. (1953) The contributions of diffusion and flow to the passage of $\mathrm{D}_{2} \mathrm{O}$ through living membranes. Acta Physiologica Scandinavica, 28, 60 .

LeE, J., Jones, J.J. \& Barraclough, M.A. (1964) Inappropriate secretion of vasopression. Lancet, ii, 792.

Rosenow, E.C., Segar, W.E. \& ZeHR, J.E. (1972) Inappropriate anti-diuretic hormone secretion in pneumonia. Mayo Clinical Proceedings, 47, 169.

Schwartz, W.B., Bennett, W., Curelop, S. \& Bartter, F.C. (1957) A syndrome of renal sodium loss and hyponatremia probably resulting from inappropriate secretion of anti-diuretic hormone. American Journal of Medicine, 23, 529.

Postgraduate Medical Journal (May 1974) 50, 312-313.

\title{
The use of anticoagulants in bacterial endocarditis
}

\author{
JoHN A. KANIS \\ B.Sc., M.R.C.P.(U.K.) \\ Royal Infirmary of Edinburgh
}

\section{Summary}

Early experience in the treatment of bacterial endocarditis with penicillin suggested that the addition of anticoagulants might improve results. This paper reports a patient with bacterial endocarditis who died from embolic cerebral damage after initiation of treatment with heparin. The evidence suggests that anticoagulants were responsible for her death and that bacterial endocarditis is a relative contra-indication to anticoagulant therapy.

\section{Introduction}

First successes with penicillin treatment in bacterial endocarditis were published in 1943 (Herrell, 1943; Florey and Florey, 1943). In 1945 Loewe reported on fifty-four patients in whom simultaneous administration of both penicillin and of heparin had proved successful in the treatment of bacterial endocarditis. Heparin was advocated (Leading article, 1946) to arrest the deposition of platelets and fibrin which would otherwise form a protective nidus for bacterial growth. Dawson and Hunter (1945) published two series of cases, in the first of which they used penicillin and heparin and in the second penicillin alone. The results of the two series were equally favourable and later experience (Bloomfield, Armstrong and Kirby, 1944; Christie, 1945; Mokotoff et al., 1944) confirmed that anticoagulant was unnecessary when adequate penicillin doses were used. It was concluded that early reports of successes with heparin and penicillin, where treatment with penicillin alone had failed, were due to inadequate penicillin doses. Thill and Meyer (1947), using penicillin in combination with anticoagulants, found a high incidence of fatal cerebral haemorrhage, leading them to suppose that $\varnothing$ the use of anticoagulants was contra-indicated in this disease.

Thus the climate of medical opinion that was perpetuated from work in the middle 1940 s was that not only were anticoagulants unnecessary, but that their use was strongly contra-indicated in bacterial endocarditis (Gavey, 1951; Toohey, 1959; Ziment, 1969) because of an increased danger of haemorrhage in areas infarcted by emboli. In 1966, this view was challenged by Lerner and Weinstein (1966), who state that 'These drugs should be used for the same reasons that they are administered to persons who do not have endocarditis.' However, the following case reports a patient with bacterial endocarditis who was given anticoagulants and who died from an intracranial haemorrhage, suggesting that this more recent viewpoint may be in error.

\section{Case report}

The patient, a 29-year-old nurse, had had rheumatic fever at the age of 14. A mitral murmur had been noted at the time but subsequent penicillin prophylaxis had not been started. Two years prior to presentation she suffered one transient episode of acute pulmonary oedema after a 'flu-like' illness, but required no long term medication thereafter. On admission she gave a 4-week history of lethargy and tiredness following an upper respiratory tract infection. Two weeks later she had developed intermittent rigors, night sweats and an unproductive cough. Three days before admission she became 